\title{
HUKUM KELUARGA DI TURKI SEBAGAI UPAYA PERDANA PEMBAHARUAN HUKUM ISLAM
}

\author{
Oleh: \\ Vita Fitria \\ MKU UNY
}

\begin{abstract}
Abstrak
Upaya pembaruan Hukum Keluarga di belahan dunia Islam mulai terealisasi pada penghujung abad 19M. Kesadaran masyarakat muslim akan tertinggalnya konsep-konsep fikh yang selama ini dijadikan rujukan, menumbuhkan semangat pembaruan dari rumusan Undang-undang lama yang telah terformat menuju Undang-undang yang lebih mampu mengakomodasi tuntutan perkembangan zaman dan kemajuan Islam itu sendiri. Turki, merupakan negara pertama yang melakukan reformasi Hukum Keluarga Muslim, dan gagasan itu muncul pada tahun 1915. Pengaruh pergesekan dengan pemikiran Barat Modern dan menilik pada perkembangan peradaban barat yang lebih maju, mendorong semangat nasionalisme masyarakat Turki untuk me'modern'kan negaranya. Undang-undang Hukum Keluarga yang merujuk pada hukum Syari'ah justru ditinggalkan. Dengan diproklamirkannya Negara Republik Turki (Turki Modern), diupayakan pula pembentukan UU Sipil Turki yang mengadopsi dari UU Sipil negara Swiss. Meskipun demikian, mayoritas bangsa Turki tetap yakin bahwa mereka adalah Muslim. Bahkan di kalangan penguasa sebagian besar menegaskan bahwa mereka tidak menolak Islam, mereka hanya mengikuti sikap Barat bahwa agama adalah masalah pribadi (yang mengatur hubungan antara individu dengan Tuhan), bukan sistem hukum yang harus dilaksanakan oleh negara.
\end{abstract}

Kata kunci: hukum keluarga, Turki, hukum Islam.

\section{Pendahuluan}

Secara historis, upaya pembaruan Hukum Keluarga di belahan dunia Islam mulai terealisasi pada penghujung abad 19M. Kesadaran masyarakat muslim akan tertinggalnya konsep-konsep fikh yang selama ini dijadikan rujukan, menumbuhkan semangat pembaruan dari rumusan Undang-undang lama yang telah terformat menuju Undang-undang yang lebih mampu mengakomodasi tuntutan perkembangan zaman dan kemajuan Islam itu sendiri.

Turki, merupakan negara pertama yang melakukan reformasi Hukum Keluarga Muslim, dan gagasan itu muncul pada tahun 1915. Setelah mengamati secara cermat berbagai fenomena yang berkaitan dengan perubahan tersebut, baru kemudian disahkan secara resmi pada tahun 1917 yaitu The Law of Family Rights. (JND Anderson, $1951: 272$ ). 
Di samping itu, pengaruh pergesekan dengan pemikiran Barat Modern dan menilik pada perkembangan peradaban barat yang lebih maju, mendorong semangat nasionalisme masyarakat Turki untuk me'modern'kan negaranya. Dalam perkembangannya, Undang-undang Hukum Keluarga yang merujuk pada hukum Syari'ah justru ditinggalkan. (JND Anderson, 1951: 288). Hal ini terlihat dengan diproklamirkannya Negara Republik Turki (Turki Modern), dengan diupayakan pembentukan UU Sipil Turki yang mengadopsi dari UU Sipil negara Swiss.

Meskipun demikian, mayoritas bangsa Turki tetap yakin bahwa mereka adalah Muslim. Bahkan di kalangan penguasa sebagian besar menegaskan bahwa mereka tidak menolak Islam, mereka hanya mengikuti sikap Barat bahwa agama adalah masalah pribadi (yang mengatur hubungan antara individu dengan Tuhan), bukan sistem hukum yang harus dilaksanakan oleh negara. ( JND Anderson, 1994: 107).

Selanjutnya, dalam kertas kerja ini penulis mencoba membahas lebih rinci lagi tentang hukum keluarga di Turki, sejarah maupun perkembangannya, materi hukum serta aplikasi dan metode pembaruannya, di samping sekilas gambaran mengenai kondisi politik sosial budaya negara Turki sebagai bagian keterkaitan dengan kompleksitas lainnya.

\section{Pembahasan}

\section{Turki dalam Sketsa Historis}

\section{Latar Belakang Historis}

Turki, merupakan negara yang berdiri di atas reruntuhan Imperium Turki Usmani yang berkuasa hampir enam abad lamanya (1342-1924 Masehi). Imperium Turki Usmani mencapai puncak kejayaan pada masa pemerintahan Sulaiman alQanuni. Wilayahnya meliputi Asia kecil, Syiria, Iraq, Mesir, Afrika Utara, wilayah pesisir Arabia, Azarbaijan, Balkan, Hungaria, dan wilayah-wilayah kecil di Volga dan wilayah diperbatasan selatan Rusia. Selain kemajuan dalam bidang militer, juga kemajuan dalam bidang administrasi, institusi sosial, arsitektur dan pekerjaan umum. Istanbul, ibu kota Turki Usmani, menjadi satu diantara kota-kota terbesar di dunia. ( Ciryll Glasse, 1999: 311).

Namun kejayaan itu perlahan-lahan mulai memudar pada tahun 1571. Akibat serangan demi serangan dari Portugis maupun Rusia, Turki Usmani kehilangan satu 
demi satu wilayahnya. Sampai di penghujung awal abad 19 Masehi, Turki Usmani masih mengalami kehancuran total. Munculnya gerakan tanzimat, yakni gerakan pembaruan Turki yang mendorong semangat berkobarnya Nasionalisme, yang pada akhirnya, melepaskan identitas sebagai bangsa Muslim. Puncaknya, terbentuknya Negara Turki Sekuler di bawah kepemimpinan Mustafa Kamal Ath-Thaturk. Kesultanan Usmani secara resmi dihapus pada tahun 1922, ditandai dengan terbentuknya Negara Republik Turki, sedang kekhilafahan Turki dihapuskan pada tahun 1924. ( Ciryll Glasse, 1999: 312).

Gerakan Nasionalisme Turki bermula sebagai reaksi terhadap kehancuran imperium Osmaniyah. Pada permulaannya, nasionalisme itu merupakan gerakan agama dengan kecenderungan progresif dan modernis. Setelah kemenangan kekuatan nasionalis dalam Perang Kemerdekaan Turki, nasionalisme itu menjadi sekuler ( H.A.Mukti Ali, 1994: 152). Selain itu, faktor-faktor politik, terutama pemberontakan negeri-negeri Arab dan tekanan-tekanan negara Eropa, juga merupakan sebab bagi politik pembaratan ini.

\section{Latar Belakang Sosial Budaya}

Berdasarkan data tahun 2009, jumlah penduduk Turki kurang lebih mencapai 72.561.312, (http://id.wikipedia.org/wiki/Turki). Penduduknya terdiri dari etnis Turk (76\%), Kurdi (15,7\%), dan lainnya (8,3\%). Agama yang dipeluk oleh penduduk Turki ialah Islam (96\%), Agnotis (2,3\%), Atheis (0,9\%), Kristen $(0,6 \%)$, dan sisanya memeluk agama lain. Umat Muslim Turki sendiri terdiri dari 82\% Sunni Hanafi, 9.1\% Sunni Shafi'i, dan 5.7\% Alevis. (http://aksesdunia.com/2011/).

Alevis adalah sebuah aliran Heterodoks yang berasal dari sekte Alawis dari Syiria. Selain itu juga ada kelompok lainnya yang dinamakan Yazidiyyah yang berkembang di kalangan keturunan Kurdi. ( Ciryll Glase, 1999: 416).

Kebudayaan Turki mempunyai beberapa persamaan dengan kebudayaan Barat. Hal ini disebabkan karena faktor sejarah dan geografis. Orang-orang Turki dari Anatolia telah menjadi penguasa dan pelindung ujung barat dari dunia muslim berabad-abad lamanya. Mereka memerintah wilayah yang luas dari Eropa Timur dalam jangka waktu yang lama. Bergaulnya orang Turki dengan orang-orang Eropa telah menciptakan pola-pola kebudayaan tertentu yang membedakan mereka dengan 
orang-orang Eropa dan Asia. Selain itu, individualisme mereka adalah satu ciri yang membedakan mereka dari rakyat Timur Tengah, dan membawa mereka dekat dengan bangsa-bangsa Eropa (Mukti Ali, 1994: 155).

\section{Latar Belakang Keagamaan}

Turki Usmani mempertahankan ajaran Islam Ortodoks dan sekaligus mencerminkan corak keislaman masyarakat Turki, yang mana utamanya mereka bertindak sebagai muslim, kemudian baru atas nama bangsa Turki (Ciryll Glase, 1999: 311). Bagi Muslim Turki, Hanafi adalah mazhab yang dijadikan rujukan secara formal sampai tahun 1926 (Tahir Mahmood, 1972: 15). Walaupun 96\% dari seluruh jumlah penduduknya beragama Islam, banyak di antara mereka yang secara sadar tidak menjalankan ajaran Islam, sebagai akibat dari kebijakan sekularisasi yang diterapkan pada abad 20 (Ciryll Glase, 1999: 416). Sisanyaterdiri dari berbagai kelompok, seperti Yahudi, Katolik Roma, dan pengikut beberapa kelompok Ortodoks Timur ( The World Book Enciclopedia, 1987:413).

Pada akhir Perang Kemerdekaan, Turki disibukkan dengan tugas pembangunan negara yang sangat berat. Perhatian para pemimpinnya terpusat pada pem-barat-an dan nasionalisasi. Kegagalan reformasi agama pada tahun 1928 membawa kepada pengabaian pendidikan agama untuk beberapa tahun lamanya (H.A.Mukti Ali, 1999: 163).

Setelah kemenangan Partai Demokrat dalam pemilihan Umum 1950, pemerintah Turki menerapkan pendidikan agama wajib di sekolah-sekolah dan memberikan kebebasan lebih luas dalam kehidupan agama kepada rakyat. Termasuk menjalin hubungan lebih rapat lagi dengan dunia Muslim, serta menciptakan kembali kondisi yang mendukung kebangkitan Islam dan membawa Turki aktif kembali dalam menangani masalah-masalah dunia Muslim (H.A.Mukti Ali, 1999: $163)$.

Kesan umum bahwa pertumbuhan nasionalisme di Turki telah membuat rakyat Turki antipati terhadap dunia Muslim lainnya, terutama setelah adanya reformasi Kemalis yang membuat rakyat Turki Modern masa bodoh terhadap Islam, adalah keliru. Menurut Mukti Ali, kesan tersebut seakan-akan memang dimunculkan oleh penulis-penulis Barat yang pendekatannya terhadap konsep perkembangan 
sekularisme di Turki adalah satu arah (H.A.Mukti Ali, 1999: 153). Dalam perkembangannya, masyarakat Turki menyadari bahwa Islam tidak bisa diabaikan untuk jangka waktu yang tidak dipastikan. Reformasi-reformasi sekuler dari tahun 1920-1930an hanya mempunyai pengaruh yang kecil di kehidupan desa. Kehidupan di kota-kota besar dan kecil justru menunjukkan adanya peningkatan kembali ketaatan orang kepada Islam, terutama setelah perubahan pemerintahan pada tahun 1950 (H.A.Mukti Ali, 1999: 164).

\section{Kehidupan Wanita}

Selama beratus-ratus tahun, pria sangat dominan dalam kehidupan masyarakat Turki. Wanita sama sekali tidak mempunyai hak sipil. Para orang tua menyusun pernikahan anak mereka dengan sistem kontrak. Mempelai wanita tidak mempunyai hak untuk menentukan pilihannya maupun menentukan perceraian dalam pernikahan.

Namun terjadi perubahan yang signifikan setelah tahun 1920. Pemerintah mulai menyusun peraturan Undang-undang yang lebih memberi keleluasaan pada wanita. Mereka diberi hak untuk memilih dan untuk mengajukan tuntutan perceraian. Terbukanya wawasan untuk menerima ide-ide dari barat secara perlahan memperbaiki posisi para wanita Turki. Kesempatan memperoleh pendidikan yang tinggi juga sangat mempengaruhi perkembangan wanita di Turki (The World Book Encyclopedia, 1987: 414).

\section{Sejarah Perundang-undangan Hukum Keluarga dan Kodifikasi Hukum}

Sejak tahun 1876 Turki Usmani telah menetapkan Undang-undang Sipil Islam (Majallat al-Ahkam al-Adliya) yang diadopsi dari hukum-hukum pada berbagai mazhab dan sebagian diambil dari materi hukum Barat. Namun Undang-undang itu kurang lengkap karena tidak mencantumkan hukum keluarga dan hukum waris. Seluruh materi hukum yang ada pada Majallat al-Ahkam al-Adliya ini belum sempat direformasi dan belum diundangkan sampai abad ke-20 (Tahir Mahmood, 1995: 82).

Untuk kasus-kasus yang berhubungan dengan hukum keluarga dan hukum waris, diatur secara resmi oleh pemerintah dengan mengadopsi penuh dari mazhab Hanafi. Dirasa adanya "penjajahan " terhadap hak-hak perempuan, terutama dalam 
masalah perceraian, maka pada tahun 1915 pemerintah mengijinkan untuk diadakannya reformasi hukum keluarga. Setidaknya ada 2 kasus yang menjadi alasan mendasar diadakannya perubahan, yaitu : pertama, kasus dimana seorang suami mengkhianati isterinya sehingga isteri tidak mendapat nafkah sebagai haknya, dan kedua, kasus dimana sang suami menderita penyakit tertentu yang bisa mengganggu kelangsungan perkawinannya (JND Anderson, 1951: 272). Sebelumnya, isteri tidak punya hak sama sekali untuk mengajukan perceraian, wewenang penuh ada pada suami.

Akhirnya pada tahun 1917, diresmikan Undang-Undang Hukum Keluarga yang diambil dari berbagai mazhab dengan menggunakan prinsip tahayyur (eclectic choice) ( Tahir Mahmood, 1995 :82). Undang-undang tersebut diberi nama The Ottoman Law of Family Rights atau Qanun Qarar al-Huquq al-'Ailah alUsmaniyyah (Tahir Mahmood, 1995: 82). Undang-undang Ottoman ini terdiri dari 156 pasal minus pasal mengenai waris. Meski tidak mengkodifikasi masalah waris, namun ini adalah terobosan awal bagi perkembangan hukum keluarga di dunia Islam.

Pergolakan politik yang terjadi di Turki pada saat itu, sangat mempengaruhi stabilitas perundang-undangan. Terutama ketika isu Turki Modern mulai mengemuka, UU ini sempat dibekukan pada tahun 1919, dengan harapan akan dapat diganti dengan UU yang lebih komprehensif. Pada tahun 1923 pemerintah membentuk panitia untuk membuat draft Undang-undang baru. Akan tetapi, para ahli hukum yang diserahi tugas tidak berhasil mencapai yang dimaksud. Akhirnya Turki mengadopsi The Swiss Civil Code Tahun 1912, yang dijadikan UU Sipil Turki (The Turkish Civil Code of 1926), dengan sedikit perubahan sesuai dengan tuntutan kondisi Turki (Khoiruddin Nasution, 2002: 93). Adopsi tersebut dilakukan karena perbedaan internal dari para ahli hukum agama yang gagal mengusahakan UU yang didasarkan pada syariah. Perbedaan tersebut meruncing ketika gagasan untuk menyatukan pengkodifikasian dari The Ottoman Family Rights 1917, UU Hanafi 1876 (The Majallah) dan hukum waris tradisional yang belum pernah terkodifikasi. Bagaimanapun juga, para ahli hukum Turki sudah mempunyai potensi yang melekat untuk menjadikan hukum Islam sebagai pertimbangan awal sebelum menetapkan Undang-Undang yang baru ( Khoiruddin Nasution, 2002: 93). 
UU Sipil Turki 1926 ini juga tidak mengadopsi sepenuhnya dari UU Sipil Swiss 1912. Bagaimanapun, tetap disesuaikan dengan tradisi dan kondisi Islam di Turki. Beberapa ketetapan yang dianggap bertentangan dengan konsep Islam tradisional, beberapa mazhab mempertimbangkannya untuk dilakukan amandemen. Keseriusan ini terlihat ketika UU Sipil 1926 ini diamandemen sebanyak enam kali dari tahun 1933-1956 agar dicapai satu kesepakatan dan kesesuaian antara UU Sipil dengan konsep-konsep Islam (Tahir Mahmood,1995: 83).

\section{Tinjauan tentang Materi Hukum Keluarga Turki}

UU Sipil Turki 1926 ini memuat tentang perkawinan, perceraian, hubungan keluarga dan kewarisan. Di samping itu juga memuat tentang kontrak dan obligasi. Di sini akan penulis paparkan secara ringkas satu demi satu materi hukum yang berhubungan dengan hukum keluarga, beserta sedikit ulasan ringkas.

\section{Pertunangan}

Khitbah adalah permintaan pihak laki-laki kepada pihak perempuan untuk dijadikan isteri melalui cara yang diketahui oleh beberapa pihak (Sayid Sabiq, tt: 150). Hukum Keluarga Turki tidak menganjurkan untuk diadakannya pesta seremonial tertentu pra pernikahan (Tahir Mamood, 1972: 19). Karena khitbah ini bertujuan untuk saling menjajaki antara pasangan calon pengantin, jadi ada kemungkinan setelah pertunangan ini akan semakin kuat ikatan batin antara keduanya atau akan menggagalkan rencana pernikahan karena ada ketidakcocokan dari masing-masing pihak.

\section{Usia Pernikahan}

Undang-undang Turki menyebutkan batas minimal umur pernikahan seorang gadis adalah 17 tahun dan 18 tahun untuk seorang laki-laki. Namun dalam kasuskasus tertentu, pengadilan dapat mengijinkan pernikahan anak laki-laki 15 tahun dan perempuan berusia 14 tahun, setelah mendapat keterangan dari orang tua mereka. Setelah dilakukan amandemen tentang batas-batas umur perkawinan, maka yang tertera dalam UU SipilTurki 1926 adalah : Seorang laki-laki dan seorang perempuan tidak dapat menikah sebelum berumur 17 dan 15 tahun. Kecuali dalam 
kasus-kasus tertentu, pengadilan mengijinkan terjadinya pernikahan umur 15 tahun laki-laki dan 14 tahun bagi perempuan, setelah adanya konsultasi / ijin dari wali atau orang tuanya (UU Sipil Turki,1926: pasal 88). Para Imam mazhab menetapkan bahwa batas usia seseorang dalam melakukan tindakan hukum adalah baligh dan berakal. Masing-masing mazhab mempunyai batasan umur yang berbeda mengenai kriteria baligh. Bagi Syafi'i dan Hambali menentukan umur 15 tahun bagi keduanya, sementara Maliki menetapkan usia 17 tahun baik bagi laki-laki maupun perempuan. Menurut Hanafi, 18 tahun bagi laki-laki dan 17 tahun bagi perempuan.Batasan ini merupakan batas maksimal, sedang batas minimal laki-laki 12 tahun dan perempuan 9 tahun, dengan alasan pada umur tersebut laki-laki sudah mimpi dan perempuan sudah haid sehingga memungkinkan terjadinya kehamilan (Muhammad Jawad Mughniyah,1999 :317-318). Masalah batasan umur perkawinan ini memang tidak diatur baik dalam Alquran maupun hadis, sehingga dengan melibatkan pengadilan dan adanya ijin dari wali, nampaknya Hukum Keluarga Turki bisa lebih kompromis dengan memberikan jalan keluar yang dilihat dari sudut kebutuhan dan kepentingan calon mempelai.

\section{Larangan Melakukan Pernikahan}

UU Turki menetapkan beberapa katagori larangan larangan dalam penyatuan melalui ikatan pernikahan. Yaitu dimana calon mempelai masih mempunyai hubungan darah dalam garis langsung, saudara laki-laki, perempuan, bibi, paman, keponakan, saudara seibu, saudara seayah, dan juga melalui perkawinan (Tahir Mahmood, 1972: 20). Pengadilan Turki juga mengenalkan adopsi secara khusus. Dalam pengadilan, adopsi disebut sebagai salah satu penghalang pernikahan, walaupun secara legal dalam yurisprodensi Islam tidak disebutkan. Pasal 121 UU Turki menegaskan bahwa adopsi dapat dihentikan oleh fakta pernikahan atau sebuah pernyataan bahwa pernikahan pernah terjadi (Tahir Mahmood 1972: 20). Mazhab Hanafi menyebutkan kriteria penyebab keharaman adalah musaharah, sesusuan, pernikahan dengan dua saudara kandung dalam satu waktu, pemilikan, musyrik dan pernikahan hamba dengan orang merdeka. Tidak ditegaskan bahwa anak hasil adopsi menghalangi terjadinya pernikahan (Muhammad Amin Ibn Abidin, tt: 28). Dalam Undang undang ini ada sedikit benturan antara posisi legal adopsi dalam 
Islam sebagaimana yang dinyatakan dalam Alquran (Alquran, 33: 44). Dalam Alquran, yang disebut anak adalah yang mempunyai hubungan secara genetis (Alquran, 33:5). Meskipun UU Turki ini mempunyai konsep resmi tentang adopsi, ketika dihadapkan pada masalah pernikahan, pada akhirnya lebih cenderung untuk menyesuaikan dengan hukum Islam.

\section{Poligami}

UU Turki melarang adanya perkawinan diatas perkawinan yang masih berlaku. Jadi sebelum adanya pernyataan tentang bubarnya perkawinan yang pertama, baik karena kematian, perceraian atau pembatalan perkawinan (UU Sipil Turki, 1926: pasal 93), perkawinan yang kedua dinyatakan tidak sah oleh Pengadilan atas dasar orang tersebut telah mempunyai kehidupan pernikahan yang masih berlaku (UU Sipil Turki,1926: pasal 112). Turki merupakan negara Muslim pertama yang secara resmi melarang poligami. Adapun yang termaktub pada UU sebelumnya yaitu The Ottoman Law of Family Rights tahun 1917, pasal 74 menjelaskan bahwa suami boleh poligami dengan syarat harus berlaku adil kepada para isterinya. Tetapi isteri berhak membuat taklik talak pada waktu akad nikah bahwa suaminya tidak akan menikah lagi. Kalau suami melanggar, maka isteri berhak minta cerai (The Ottoman Family Right, pasal 38).

Sebenarnya poligami telah dikenal bangsa-bangsa dunia jauh sebelum Islam lahir. Islam datang untuk mengatur poligami. Surat An-Nisa' ayat 3 yang membolehkan poligami, merupakan jalan keluar dari kewajiban berbuat adil yang tidak terlaksana sebelumnya (Ahmad Azhar Basyir, 1996: 35). Kondisi sosial politik negara Turki pasca 1920, telah membuat pergeseran masyarakat dalam berbagai bidang, terutama tidak dapat diberlakukannya poligami, karena tidak sesuai dengan situasi dan perkembangan.

\section{Resepsi Pernikahan}

Disebutkan dalam UU Sipil Turki, bahwa resepsi pernikahan boleh dirayakan sesuai dengan agama yang dianut, hanya saja, sebaiknya syarat-syarat formalitas seperti pendaftaran atau pencatatan perkawinan dipenuhi dulu sesuai dengan peraturan yang berlaku. Para ulama sepakat bahwa penyelenggaraan Walimatul Urs 
adalah sunat muakkad, sementara menghadiri undangannya adalah wajib. Kecuali menurut Hanafi bahwa menghadiri undangan hukumnya sunnah. ( Wahbah Al Zuhaili, 1989: 127).

\section{Pembatalan Pernikahan}

Pasal 112 UU Sipil Turki menyebutkan bahwa pernikahan harus dibatalkan bila dalam kondisi : 1). Salah satu pihak telah berumah tangga saat menikah, 2). Pada saat menikah salah satu pihak menderita penyakit jiwa, 3). Termasuk dalam pernikahan yang dilarang. Menurut mazhab Hanafi, pernikahan dianggap batal apabila ada rukun dan syarat pernikahan yang tidak dipenuhi. Bila hal itu terjadi, dan pasangan telah melakukan hubungan suami isteri, hakim harus memisahkan secara paksa dan tidak berlaku iddah bagi wanitanya. (Wahbah Al-Zuhaili, 1989:112).

\section{Pernikahan yang Tidak Sah}

UU Turki memberi kewenangan kepada pengadilan untuk menyatakan ketidakabsahan suatu pernikahan berdasarkan alasan-alasan sebagai berikut : 1). Pada saat pernikahan, salah satu pihak merasa dirugikan karena alasan alasan tertentu, 2). Salah satu pihak pada dasarnya tidak punya keinginan sungguh-sungguh untuk menikah dengan pasangannya. 3). Salah satu pihak mempunyai anggapan yang mendasar bahwa pasangannya tidak memiliki kualitas atau kriteria seperti yang diharapkan. 4). Salah satu pihak merasa tertipu dengan kepribadian/ karakter moralnya. 5). Salah satu pihak mempunyai penyakit yang membahayakan atau salah satu pihak masih di bawah umur, 6). Salah satu pihak menikah di bawah paksaan dan ancaman orang lain yang membahayakan hidupnya, kesehatannya atau membahayakan orang-orang yang dekat dengannya ( UU Sipil Turki, 1926 : pasal 20).

\section{Perceraian}

UU Turki menyebutkan tentang 6 alasan yang memungkinkan masing-masing pihak untuk mengajukan perceraian ( UU Sipil Turki, 1926: pasal 20). Pengadilan juga membuka kemungkinan adanya rekonsiliasi antar pihak. Namun jika rekonsiliasi tak terjadi, maka tetap perceraian bisa terjadi. 
Keenam alasan tersebut adalah : 1). Salah satu pihak telah melakukan perselingkuhan/perzinahan, 2). Salah satu pihak menyakiti pihak lain, yang menyebabkan luka-luka, 3). Salah satu pihak melakukan tindakan kriminal yang mengganggu kelangsungan hubungan perkawinan, 4). Salah satu pihak meninggalkan tempat tinggal dengan alasan yang tidak jelas, sampai batas waktu sekurang-kurangnya 3 bulan, 5). Salah satu pihak mempunyai penyakit jiwa yang membahayakan kehidupan perkawinan, yang dinyatakan oleh surat keterangan dokter dalam waktu sekurang-kurangnya 3 tahun, 6). Perselisihan antara suami isteri yang terjadi terus menerus yang sudah tidak bisa didamaikan lagi.

\section{Kompensasi (Ganti Rugi) dalam Perceraian}

Pengadilan menetapkan bahwa pihak yang bersalah membayar ganti rugi kepada pihak yang dirugikan secara fisik, keuangan, atau dirugikan reputasinya (Tahir Mahmood, 1972: 24). Aturan tambahan dari UU Sipil Turki yang memberikan hak kepada pengadilan untuk mengatur bahwa pihak yang diceraikan tidak peduli bersalah atau tidak, harus diberi ganti rugi oleh pihak yang menceraikan selama pihak pertama belum menikah lagi dalam periode tak lebih dari 1 tahun dari tanggal perceraian ( Tahir Mahmood, 1972: 24).

\section{Hukum Waris}

Tentang Kewarisan dalam UU Sipil Turki diatur dalam buku ketiga. Buku ini memuat tentang aturan kewarisan tanpa wasiat, yang diadopsi dari UU Sipil Swiss. Undang-undang ini sekaligus menggantikan UU Hanafi yang berlaku sebelumnya hingga tahun 1926 ( Tahir Mahmood, 1972: 24).

Dalam UU kewarisan ini, prinsip kesetaraan antara laki-laki dan perempuan yang berkaitan dengan warisan, berbeda dengan apa yang ada dalam hukum Islam, dimana laki-laki dan perempuan mendapatkan bagian yang sama. Sedang dalam Alquran, laki-laki mendapat bagian dua kali dari yang diterima perempuan (Tahir Mahmood, 1972: 24).

\section{Aplikasi dan Metode Pembaruan Undang-undang Hukum Keluarga di Turki}


Anderson mencatat ada 4 metode umum yang digunakan sarjana dalam melakukan pembaruan hukum keluarga Islam kontemporer, yaitu 1). Tahsis alqada' atau siyasah as-syar'iyyah atau lewat aturan yang bersifat prosedural dan administratif sesuai dengan tuntutan zaman modern dengan tidak merubah substansi hukumnya, 2). Tahayyur atau memilih salah satu dari sekian pandangan mazhab fikh yang ada, dan talfiq atau menggabungkan pandangan sejumlah mazhab dalam satu masalah tertentu, 3). Reinterpretasi teks syari'ah, 4). Menggunakan alternatif, misalnya menggunakan administrasi tetapi tidak menyentuh aspek syari'ah ( JND Anderson, 1994: 72).

Menilik dari keempat metode diatas, Turki menggunakan prinsip tahayyur dalam aturan taklik talak yang terdapat dalam UU tahun 1917 dimana isteri berhak mencantumkan dalam taklik talak dalam masalah poligami. Adapun pelarangan poligami yang terdapat dalam UU Sipil Turki 1926, menggunakan prinsip ijtihad dengan reinterpretasi teks, yaitu penafsiran ulang terhadap Surat an-Nisa'(4): 3, bahwa keadilan yang dibutuhkan untuk bolehnya poligami bukan hanya dalam hal nafkah, tapi juga termasuk rasa cinta. Karena itu, menurut Pearl --seperti yang dikutip Khoiruddin Nasution dari Muslim Family Law, --ada keberanjakan dari esensi hukum Islam. Apa yang dimaksudkan Pearl ini adalah adanya usaha penafsiran ulang terhadap teks nash untuk memenuhi kebutuhan dan tuntutan zaman. (Khoiruddin Nasution, 2002: 282). Dalam penafsiran ulang ini tergantung dari pemahaman kontekstual masing-masing mujtahid, ada yang menghubungkan dengan latar belakang turunnya ayat, dan menghubungkan dengan an-Nisa : 129 . Ada juga yang mengkaitkan dengan ayat sebelumnya an-Nisa: 1-2, yang bisa disimpulkan bahwa an-Nisa: 3 berkaitan dengan urusan harta anak yatim. (Khoiruddin Nasution, 2002: 283).

Adapun Tahir Mahmood, menawarkan beberapa metode yaitu: 1). Extra Doctrinal Reform yaitu penggabungan beberapa mazhab atau mengambil mazhab lain diluar mazhab utama, 2). Intra Doctrinal Reform yaitu pembaruan hukum dengan interpretasi yang sama sekali baru terhadap nash yang ada, 3). Regulatory Reform yaitu positifikasi hukum-hukum yang bersifat administratif, 4). Codification yaitu positifikasi hukum-hukum Islam klasik yang sudah ada (Tahir Mahmood, 1972 :267-270). .Intra Doctrinal Reform nampaknya lebih menyentuh pada hukum waris 
Turki 1926, yang diadopsi dari hukum Swiss. Yang sangat signifikan adalah seperti disebutkan dalam Alquran bahwa bagian perempuan adalah seperdua bagian lakilaki. Namun dalam hukum waris Turki ada kesetaraan antara laki-laki dan perempuan.

Penetapan batasan umur pernikahan menggunakan prinsip tahayyur, yang juga menyepakati pendapat Asy-Syaukani bahwa perkawinan Aisyah adalah perkecualian. UU Turki ini memberikan dispensasi pada kasus-kasus tertentu, di mana perkawinan di bawah umur harus dengan ijin pengadilan dan di bawah persetujuan wali.

Larangan pernikahan, pembatalan pernikahan, pernikahan yang tidak sah, merupakan kodifikasi, karena mengangkat hukum Islam sebagai bagian hukum yang dipositifkan. Dalam larangan pernikahan sehubungan dengan kasus adopsi, UU Turki lebih berpegang pada prinsip tahayyur dan talfiq.

Pertunangan, upaya kodifikasi hukum Islam klasik dengan cara-cara yang digunakan adat setempat. Begitu juga Resepsi Pernikahan, hanya bersifat administratif. Mengenai kompensasi pernikahan, berbeda dengan kompensasi yang ditetapkan dalam hukum Islam. Penetapan hukumnya bersifat tahayyur.

\section{Penutup}

Mencermati dinamika perkembangan pemikiran hukum Islam di Turki yang datang jauh lebih awal dibanding negara-negara Muslim lainnya, ada beberapa hal yang bisa ditegaskan, yakni:

1. UU Sipil Turki tahun 1926 yang diadopsi dari UU Sipil Swiss tahun 1912, tidak sepenuhnya meninggalkan aturan-aturan yang ada dalam hukum Islam, dalam beberapa kasus masih sangat relevan dengan hukum Islam yang berlaku.

2. UU Sipil Turki ini lebih mengangkat status kaum wanita terutama adanya larangan poligami, kebebasan si isteri mengajukan tuntutan perceraian dengan alasan-alasan tertentu, juga adanya kesetaraan dalam warisan.

3. Perubahan demi perubahan dalam Undang-undang yang terjadi, dari Majallah (1876), The Law of Family Rights (1917), UU Sipil Turki Tahun 1926, adalah karena pengaruh kondisi sosial politik yang belum stabil, yang mana masyarakat Turki pada waktu itu masih merasakan krisis identitas. 


\section{DAFTAR PUSTAKA}

Abidin, Muhammad Amin Ibn, Hashiyah Radd al-Muhtar, Jilid II, Beirut : Dar alFikr, tt.

Ali, H.A.Mukti, Islam dan Sekularisme di Turki Modern, Jakarta: Djambatan, 1994.

Departemen Agama RI., Alquran dan Terjemahnya, Jakarta: PT. Intermasa, 1986.

Anderson, J.N.D., Hukum Islam di Dunia Modern, alih bahasa : Machnun Husein, Yogyakarta : Tiara Wacana, 1994.

-----------, Recent Development in Shari'a Law V: The Dissolution of Marriage dalam The Muslim World,41, 1951.

Basyir, Ahmad Ashar, Hukum Perkawinan Islam, cet.8, Yogyakarta : Perpustakaan Fakultas Hukum UII , 1996.

Glasse, Cyrill, Encyclopedi Islam, alih bahasa: Ghufron A. Mas'adi, Jakarta: P.T. Raja Grofindo Persada, 1999.

Mahmood, Tahir, Family Law Reform in The Muslim World, New Delhi : The Indian Law Institut, 1972.

Statutes Personal Law in Islamic Countries (History, Texs and Comparative Analysis), New Delhi : Academi of Law and Religion, 1995.

Mughniyah, Muhammad Jawad, Fiqh Lima Mazhab, cet. 4, Alih bahasa: Afif Muhammad, Jakarta : Lentera Basritama, 1999. 
Nasution, Khoiruddin, Status Wanita di Asia Tenggara : Studi Terhadap Perundang-Undangan Perkawinan Muslim Kontemporer di Indonesia dan Malaysia, Jakarta : INIS, 2002.

Sabiq, Sayid, Fiqh al-Sunnah, Jilid II, Jedah: Maktabah al-Hadimat al-Hadisah, tt.

The World Book Encyclopedia, Vol. 19, USA : World Book,Inc, 1987.

Zuhaili, al, Wahbah, Al-Fiqh al-Islami wa Adillatuhu, Vol. VII, Beirut: Dar alFikr,1989.

(http://aksesdunia.com/2011/7-negara-di-eropa-dengan-populasi-muslim-terbanyak/) (http://id.wikipedia.org/wiki/Turki). 